\title{
KŪRYBIŠKUMAS, ITINKLINTAS MOKYMAS(IS) IR VISAPUSIŠKESNIŲ PAŽINTINIŲ GEBĖJIMŲ UGDYMAS UNIVERSITETINĖSE STUDIJOSE
}

\author{
Vilhelmina Vaičiūnienė, Viktorija Mažeikienè \\ Mykolo Romerio universiteto \\ Filosofijos ir humanistikos institutas \\ Ateities g. 20, Lt-08303 Vilnius, Lietuva \\ Telefonas (+370 6) 5263276 \\ Elektroninis paštas: vvaciun@mruni.eu,vmazeikiene@mruni.eu \\ Pateikta 2014 m. kovo 2 d., parengta spausdinti 2014 m. kovo 31 d.
}

doi:10.13165/SMS-14-6-1-02

Anotacija. Visos kada nors susiformavusios žmoniu grupés ar ịvairių interesu vienijamos bendruomenès atsirado dèl žmoniu kürybos ir kürybiškumo, dalijimosi informacija ir žiniomis, ịvairiomis fizinèmis jausmu ir emociju išraiškos formomis, žodiniais ir simboliniais kūriniais. Kita vertus, net ir mažiausios inovacijos visuomet duodavo akstina socialinio gyvenimo kaitai. Bene didžiausias su naujosiomis technologijomis susijęs pokytis mokymo(si) kontekste yra naujos paradigmos, kurioje susiliejo du - mokymo ir mokymosi - procesai, atsiradimas. Kürybiškumas neatsiejamas nuo žiniu kürimo proceso šiuolaikinejje visuomeneje. Šiame straipsnyje remiamasi trimis prieigomis prie kūrybiškumo ịtinklinto mokymosi ir visapusiškesniu pažintiniu gebëjimu ugdymo kontekste: Czikszentmihalyi sistemu teorija, Sternbergo ir Lubarto investavimo ị kürybiškuma teorija ir grupe požiūriu j kürybiškumą, kuriu dèmesio centre - problemu nustatymas ir sprendimas. Kalbant apie įtinklinta mokymą(si) ir visapusiškesniu pažintiniu gebèjimu ugdyma universitetinèse studijose, svarbu pažvelgti i kürybiškuma (i) kaip koncepta ir (ii) kürybiškuma edukaciniame kontekste. Kürybiškumas turi daug sąsaju su kritiniu raštingumu - kritiniu rašymu ir skaitymu, gebejjimu analizuoti, vertinti ir kurti

Socialinių mokslų studijos / Societal Studies

(C) Mykolo Romerio universitetas, 2014

(C) Mykolas Romeris University, 2014
ISSN 2029-2236 (print), ISSN 2029-2244 (online) http://www.mruni.eu/lt/mokslo_darbai/SMS/ http://www.mruni.eu/en/mokslo_darbai/SMS/ 
ivairiausius tekstus (spausdintinius, elektroninius, vaizdinius, daugiaterpius) bei gauta informacija sèkmingai pritaikyti kasdieniame gyvenime siekiant gyvenamos socialinès aplinkos pokyčių. Saityno 2.0 eroje naujosios technologijos (ypač ju socialinis pobūdis) leido plačiai naudotis kūrybos priemonemis, kūriniu publikavimu, vertinimu ir kritikavimu, atsirado naujos kūrybiškumo ugdymo bei skatinimo ir kürybiškumo produktu viešinimo galimybès. Todèl ir aukštajam mokslui tapo svarbu pasinaudoti būtent socialiniu technologiju teikiamomis kūrybiškumo ir daugelio kitų susijusiu gebejjimu (skaitmeninio raštingumo, mediju raštingumo, kritinio raštingumo, bendradarbiavimo ir komunikacijos igūdžiu) ugdymo galimybèmis. Galvojant apie greitai kintantị mūsu gyvenama pasauli ir jo realijas, bütini tyrimai, kaip mokymas(is) vyksta virtualioje aplinkoje ir kaip virtualumas ir tinklinimasis veikia kürybiškumą ir patį žmogu.

Reikšminiai žodžiai: kūrybiškumas, ịtinklintas mokymas(is), pažintiniai gebèjimai, kritinis raštingumas, naujosios technologijos.

\section{Ivadas}

Visuomenės raidai visais laikais ịtaką dare žinios, komunikacijos būdai ir kuriamos naujovès. Pasak Sales, Fournier ir Sénéchal ${ }^{1}$, šiuolaikinè visuomenè „apsèsta“ “žinių ir informacijos kaupimo bei ịvairiausių nūdienos komunikacijos ir kūrybiškumo apraiškų. Visos kada nors susiformavusios žmonių grupes ar įvairių interesų vienijamos bendruomenės (pvz., socialiniai tinklai) atsirado dèl žmonių kūrybos ir kūrybiškumo, dalijimosi informacija ir žiniomis, žodiniais kūriniais, ̨̇vairiomis fizinėmis jausmų ir emocijų išraiškos formomis, simboliniais kūriniais; ir tuo pat metu net ir mažiausios inovacijos visuomet duodavo akstiną socialinio gyvenimo kaitai. Sales, Fournier ir Sénéchal²nuomone, kad ir kaip bepavadintume šiuolaikinę visuomenę žinių visuomene, informacijos visuomene, ịtinklinta visuomene, kūrybiška visuomene - reikia pripažinti, kad mūsų gyvenimas dar niekada taip stipriai nepriklausė nuo sukauptų žinių, naujųjų informacijos ir komunikacijos technologijų, besiformuojančių tinklų, mokslinių tyrimų bei nuolatinio, didžiulị pagreitị igavusio kūrybiškumo poreikio kiekvienoje srityje; bet čia reikia nepamiršti vieno dalyko - kūrybiškumas tuo pat metu gali būti inovatyvus, destruktyvus bei adaptyvus. Kūrybiškumas šiuolaikinèje ịtinklintoje visuomenèje apibūdinamas netgi kaip „refleksyvus“: kūrèjo darbas, praeityje laikytas nereikšminga ekonomine veikla, vis dažniau suvokiamas kaip pažangiausia naujų gamybos būdų ir naujų darbo santykių raiška, atsiradusi dèl pastarųjų kapitalizmo sistemos pokyčių, o komunikacija tapo „refleksyvaus kūrybiškumo katalizatoriumi“"

1 Sales, A.; Fournier, M.; Sénéchal, Y., Knowledge, Communication, Reflexive Creativity and Social Change. Sales, A.; Fournier, M. (eds.), Knowledge, Communication and Creativity. London: SAGE Publications Ltd., 2007, p. 3-27.

$2 \quad$ Ibid., p. 3.

3 Ibid., p. 3-4. 
Bene didžiausias su naujosiomis technologijomis susijęs pokytis mokymo(si) kontekste yra naujos paradigmos, kurioje susiliejo du - mokymo ir mokymosi - procesai, atsiradimas. Kol mokslininkai tiria, koki poveiki naujosios technologijos daro besimokančiajam (gerai, kad praèjo laikotarpis, kai visus buvo apėmusi euforija dèl naujųjų technologijų ir pagaliau imta žvelgti i jų atnešamus pokyčius objektyviau ir kritiškiau), aiškèja keli dalykai: kūrybiškumas neatsiejamas nuo žinių kūrimo proceso šiuolaikinèje visuomenèje, kad ir kaip ją apibūdintume. Kaip pastebi Sales, Fournier ir Sénéchal ${ }^{4}$, šiuolaikinès visuomenès transformacijos vyksta dèl to, kad žinios, komunikacija, tinklai ir kūrybiškumas - šie tarpusavyje susiję elementai - tuo pat metu yra socialinių pokyčių šaltinis ir pasekmè. Kalbant apie ịtinklintą mokymą(si) ir visapusiškesnių pažintinių gebejjimų ugdymą universitetinėse studijose, svarbu pažvelgti ị kūrybiškumą (i) kaip konceptą ir (ii) kūrybiškumą edukaciniame kontekste.

Straipsnyje pristatomas tyrimo objektas - kūrybiškumo fenomenas. Tyrimo problema apima šiuos klausimus: kaip kūrybiškumo konceptas interpretuojamas šiuolaikinejje mokslinèje literatūroje ir koks kūrybiškumo vaidmuo ịtinklinto mokymo(si) ir visapusiškesnių pažintinių gebejjimų ugdymo kontekste. Tyrimo tikslas - aprašyti, kokios aktualios kūrybiškumo dimensijos tiriamos nūdienos tyrèjų. Tyrimo metodas - aprašomoji mokslinès literatūros analizè.

\section{Kūrybiškumas - sąvoka}

Sternber ${ }^{5}$ kūrybiškumą apibrèžia kaip gebejjimą kurti naujus (t. y. originalius, netikètus), kokybiškus ir tinkamus (t. y. naudingus, atitinkančius ir peržengiančius užduoties / siekiamo tikslo ribas) darbus / kūrinius. Jis pabrèžia, kad kūrybiškumas yra labai plati sąvoka, svarbi tiek individo (pvz., dirbančio savo darbą ar atliekančio kasdienius darbus), tiek visuomenès (pvz., darbai, vedantys prie naujų mokslinių atradimų, naujų meno srovių atsiradimo, naujų išradimų ar naujų socialinių programų) lygmenyse. Svarbus ir ekonominis aspektas - kūrybiškumas leidžia kurti naujas darbo vietas ir naujus produktus ${ }^{6}$. Tačiau ekonominis aspektas negali būti atsietas nuo socialinio, kultūrinio, ugdymo aspektų. Todèl tyrèjai, pvz., Etzkowitz ir Leydesdorff', kalba apie „trigubo sraigto sistemos“ (angl. Triple Helix System) modeli - struktūrinị valdžios institucijų, pramonès įmonių ir mokslinių tyrimų ịstaigų bendradarbiavimą.

4 Sales, A.; Fournier, M.; Sénéchal, Y., supra note 1, p. 4.

5 Sternberg, R. J. Creativity. Sternberg, R. J.; Lubart, T. I.; Kaufman, J. C.; Pretz, J. E. (eds.). The Cambridge Handbook of Thinking and Reasoning. New York: Cambridge University Press, 2005, p. 351-369.

$6 \quad$ Ibid., p. 351.

7 Etzkowitz, H.; Leydesdorff, L. The Dynamics of Innovation: From National Systems and "Mode 2" to a Triple Helix of University - Industry - Government Relations. Research Policy. 2000, 29(2): 109-123, cit. Sales, A.; Fournier, M.; Sénéchal, Y. Knowledge, Communication, Reflexive Creativity and Social Change. Sales, A.; Fournier, M. (eds.), Knowledge, Communication and Creativity. London: SAGE Publications Ltd., 2007, p. 3-27. 
Siekiant užčiuopti kūrybiškumo esmę, svarbu matyti jị sąveikos tarp individo ir jo aplinkos kontekste: kad ir kokie svarbūs būtų asmens vidiniai bruožai, jo kūrybiškumas nebus iki galo suvoktas, neatkreipus dèmesio ị kūrybos sritị ir laikmetị, kada individas kuria ${ }^{8}$.

1) Kūrybiškumo, įtinklinto mokymo(si) ir visapusiškesnių pažintinių gebėjimų ugdymo sąsajas geriausiai atskleidžia trys požiūriai i kūrybiškumą: Czikszentmihalyi sistemų teorija ${ }^{9}$, Sternbergo ir Lubarto investavimo ị kūrybiškumą teorija ${ }^{10}$ ir grupe požiūrių i kūrybiškumą, kurių dėmesio centre - problemų nustatymas ir sprendimas ${ }^{11121314}$. Šiame straipsnyje remiamasi šiomis trimis prieigomis, kadangi:

2) Kūrybiškumo tyrèjai neretai pabrěžia, kad gilinantis ị kūrybiškumą svarbus nuosaikumas ir nuomonių îvairiapusiškumas ${ }^{15}$;

3) Sistemų teorija ir investavimo teorija tyrejų priskiriamos vadinamųjų „susiliejančiųjų“ (angl. confluence approaches) požiūrių grupei: „susiliejimu“ čia ìvardijama tai, kad daugybès komponentų sąveika yra būtina kūrybiškumui pasireikšti, ugdyti, suvokti ir paaiškinti ${ }^{16}$.

Problemų sprendimo ir radimo prieigos prie kūrybiškumo (jų ištakos - kognityviné psichologija) remiasi pažinimo ir žinių kūrimo procesų tyrimais. Šio požiūrio dèmesio centre - kuriantis žmogus bei jo žinios ir pažinimo procesai ${ }^{17}$. Nūdienos visuomenejje kūrybiškumas ypač svarbus: pasaulis keičiasi greičiau nei kada nors iki šiol, ir žmonèms tenka nuolat susidurti su naujais reiškiniais, todèl reikia visą gyvenimą nesiliauti mokytis ir mąstyti naujai ${ }^{18}$.

Czikszentmihalyi ${ }^{19}$ pabrèžè socialinio konteksto, iš kurio randasi kūrybiškumas ir inovacijos, svarbą, atkreipdamas demesị ị tai, kad kuriančio individo buvimas ir veikla konkrečioje vietoje ir konkrečiu laiku, kur tuo pat metu susitelkia ir kiti žmo-

9 Czikszentmihalyi, M. A. Systems Perspective on Creativity. Sternberg, R. J. (ed.). Handbook of Creativity. New York: Cambridge University Press, 1999, p. 3-17.

10 Sternberg, R. J. Creativity as a Habit. Tan, A. G. (ed.). Creativity: A Handbook for Teachers. Singapore: World Scientific Publishing Co. Pte. Ltd., 2007, p. 3-25.

11 Weisberg, R. W. Creativity: Understanding Innovation in Problem Solving, Science, Invention, and the Arts. Hoboken, NJ: Wiley, 2006.

12 Runco, M. A. Problem Finding, Problem Solving, and Creativity. Norwood, NJ: Ablex, 1994.

13 Kozbelt, A.; Beghetto, R. A.; Runco, M. A. Theories of Creativity. Kaufman, J. C.; Sternberg, R. J. (eds.). The Cambridge Handbook of Creativity. Cambridge: Cambridge University Press, 2010, p. 20-47.

14 Tan, O. S. Problem-based Learning and Creativity. Singapore: Cengage Publishing, 2009.

15 Kozbelt, A.; Beghetto, R. A.; Runco, M. A., supra note 13, p. 20.

16 Sternberg, R. J., supra note 5, p. 359.

17 Kozbelt, A.; Beghetto, R. A.; Runco, M., A., op. cit., p. 33.

18 Sternberg, R. J., supra note 10, p. 7.

19 Czikszentmihalyi, M. A., supra note 9, p. 3. 
nès, kuriantys ar dirbantys toje pačioje srityje, gali duoti postūmị kūrybiškumo proveržiui, pvz., tapybos ir skulptūros meno suklestejimas XIV a. Florencijoje, kompiuterių kūrimas 7-8 dešimtmečių Kalifornijoje, Pietryčių Azijos industrializacija XX a. paskutiniame ketvirtyje. Remdamasis tokiais pavyzdžiais, Czikszentmihalyi plètoja savo sistemų teoriją, susiedamas kūrybines individų pastangas su jų dirbamos srities būsena konkrečiame kontekste ir laike bei savybėmis ir požiūriais tų, kurie turi įtakos nustatyti toje srityje besireiškiančiu kūrybinių pastangų vertę. Ṣ̌ tyrèją domina, kaip sąveikauja kultūriné-simboliné sfera (angl. domain) (t. y. informacija ir žinios, pvz., knygos, filmai, kursai, ịrankiai, vertybès, dominuojančios praktikos ir kt.), socialiné sfera (angl. field) (t. y. žmonès, srities ekspertai, vadinamieji „vartininkai“, pvz., kino industrija, auditorija, kritikai, galeriju savininkai ir kt.) ir kuriantis individas (angl. individual). Pasak Czikszentmihalyi ${ }^{20}$, psichologai linkę žvelgti ị kūrybiškumą tik kaip ị psichinị procesą, tačiau jis yra ne mažiau svarbus ir kultūrineje bei socialinejje plotmèse. Todèl kūrybiškumas nẻra vien tik individo vidinių savybių išraiška ir produktas, bet ir visos socialinès-kultūrinès sistemos, kuri patiria ir ịvertina individualios kūrybos apraiškas. Tad vienodai svarbus yra ir individas, ir jo kūrybą patirianti auditorija: kūryba galima, kai individas sąveikauja su jo srityje sukauptomis žiniomis ir žino, kokios taisyklès toje srityje galioja. Individas turi sukurti naują jau egzistuojančio turinio variaciją, kurią paskui turi pastebèti ir ịvertinti socialinè sfera: tik kai socialinè sfera pripažįsta kūrinio vertę, kūrinys gali būti ịvardintas kūrybišku. Vertètų paminèti Czikszentmihalyi ${ }^{21}$ nubrěžtą skirtumą tarp originalumo ir kūrybiškumo: šis autorius mano, kad idèja ar produktas gali būti ̨̣vardijami kaip originalūs, tačiau jie nèra kūrybiški tol, kol jų nevaliduoja socialinè-kultūrinè aplinka.

Pasak Czikszentmihalyi ${ }^{22}$, kūrybiškumo rezultatas - pokytis kūrybos srityje, kuris išliks laike. Kai kuriems žmonėms pavyksta pasiekti pokyčių dèl savo asmeninių bruožų, o kai kuriems todèl, kad jie tam tikru metu užima kūrybiškumui palankią padèti, pvz., jiems prieinamos žinios, priemonès, arba jų socialinè padètis jų nevaržo ir jie gali eksperimentuoti. Labai svarbi ir gyvenamoji kultūra: jeigu jos tradicija stebèti gamtą, užrašyti ar kitais būdais fiksuoti mintis, naudoti ịvairias simbolines sistemas (pvz., matematines), yra didesnè tikimybė, kad individo kūrybiškos ižvalgos bus pastebètos, ịvertintos, pripažintos. Kalbant apie kultūrinį kontekstą, kūrybiškumui reikštis reikalinga žmonių bendruomenè, kurią vienija mąstymo ir veiklos būdai, kur žmonès mokosi vienas iš kito ir imituoja vieni kitų veiksmus. Apie kūrybiškumą galima galvoti ir kaip apie pokyti memuose - kultūriniuose elementuose, perduodamuose tarp žmonių per imitaciją (tokių elementų pavyzdžiai gali būti posakiai, patarlès, grafiniai simboliai, religinès sąvokos, melodijos ir pan.). Czikszentmihalyi ${ }^{23}$ čia remiasi garsiuoju genetiko R. Dawkins veikalu The Selfish Gene (1976), kuriame

\footnotetext{
20 Czikszentmihalyi, M. A., supra note 9, p. 11.

21 Ibid., p. 7.

22 Ibid., p. 3.

23 Ibid., p. 5.
} 
memai minimi genetikos mokslo kontekste, tačiau platesniame kontekste neretai kalbama apie memus kaip kultūrinius elementus. Pasak Czikszentmihalyi ${ }^{24}$, kultūriniai memai iš tiesų panašūs i̇ genus, nes jie perduoda informaciją, pvz., natos pasako, ką dainuoti, receptas - kaip gaminti, skirtumas tik tas, kad genetinès instrukcijos perduodamos cheminiais kodais, o kultūrinès - per mokymąsi. Tačiau kad naujas memas būtų pavadintas kūrybišku, jis turi būti socialiai vertinamas. Būtent socialinis ịvertinimas padeda atskirti paprasčiausiai keistas idejjas nuo tų, kurios yra originalios bei kūrybingos.

Czikszentmihalyi sistemų teorijoje nuolat pabrèžiama kultūrinès ir socialinès sferų svarba kūrybiškumui, tačiau pripažįstama, jog asmens bruožai irgi turi ịtakos, pvz., genetika, vidinè motyvacija, kognityviniai gebejjimai, tam tikroje situacijoje reikalingi bruožai (o būtent kokie - priklauso nuo konkrečios srities ir laikmečio); svarbi ir individo aplinka vaikystejje, etninès ir šeimos tradicijos, kultūrinis kapitalas (mokymasis namie, mokykloje, mokytojų įtaka), marginalumas (socialinis, etninis, ekonominis, religinis). Nors ir pastebeta, kad daug kūrybingų asmenybių užaugo netipiškoje aplinkoje, tačiau spejjama, kad didelis skurdas ir užribis teigiamai neveikia kūrybinių galių. Todèl Csikszentmihalyii ${ }^{25}$ daro išvadą, kad kūrybiškumui svarbu ne kiek talentingų individų gimsta, bet ir prieiga prie įvairių simbolių sistemų ir socialinès sistemos atsako ị naujoviškas idejjas. Czikszentmihalyi sistemų teorija labai svarbi tiriant įtinklintą mokymąsi ir studentų visapusiškesnių pažintinių gebėjimų ugdymą: šioje srityje nuolat iškyla prieštaravimas tarp dviejų dalykų. Neretai euforiškai teigiama, kad įtinklinimas panaikina hierarchijas ir išlaisvina kūrybines galias. Tačiau vis dažniau mokslininkų diskusijose atkreipiamas dėmesys ị nuolat didejjantị vaizdo dominavimą prieš tekstą, o neraštingumas (kuris šiuolaikinèje visuomenèje igijęs daugybę apraiškų, pvz., tai gali būti neišugdyti rašymo ir skaitymo, informacinio raštingumo, kompiuterinio raštingumo, kritinio raštingumo gebejjimai) tampa grèsmingas. Pasak R. Miliūnaitès ${ }^{26}$, neraštingi žmonès negali būti laisvi ir kūrybingi tai pigios darbo jègos minia, kuria lengva manipuliuoti.

\section{Kūrybiškumas ir kritinis raštingumas įtinklintame mokyme(si)}

Kūrybiškumas turi daug sąsajų su kritiniu raštingumu - kritiniu rašymu ir skaitymu, gebejimu analizuoti, vertinti ir kurti įvairiausius tekstus (spausdintinius, elektroninius, vaizdinius, daugiaterpius) bei gautą informaciją sėkmingai pritaikyti kasdieniame gyvenime siekiant gyvenamosios socialinès aplinkos pokyčių. Czikszen-

Czikszentmihalyi, M. A., supra note 9, p. 5.

26 Miliūnaite, R. Skaitymo ir raštingumo darna: kaip jos siekti? Lietuvos edukologijos universiteto organizuotos konferencijos Visa Lietuva skaito vaikams: raštingumo ugdymas skaitant pranešimas [interaktyvus]. Vilnius, 2013 m. gruodžio 6 d. [žiūrèta 2013-12-20]. <http://www.kalbosnamai.lt/images/dokumentai/skaitymo_ra\%C5\%A1tingumo\%20konferencija\%202013.pdf>. 
tmihalyi sistemų teorija puikiai paaiškina socialinio-kultūrinio konteksto sąsajas su kuriančio individo pastangomis, tačiau nepateikia paaiškinimo, kaip pats individas gali paveikti socialinị kontekstą, kad socialinė aplinka pripažintų jo kūrybą. Kūrybiškumo fenomeną atskleisti gali padèti Sternbergo ir Lubarto investavimo ị kūrybiškumą teorija. Jos principas buy low, sell high ir ekonominiam kontekstui būdinga terminologija pateikia gana universalų dalyką: imk tai, kas nepopuliaru, ịveik pasipriešinimą ir galbūt tau labai pasiseks ${ }^{27}$. Būtini 6 tarpusavyje susiję ištekliai: intelektiniai gebejjimai, žinios, mąstymo stiliai, asmenybès bruožai, motyvacija ir aplinka. Sternberg ${ }^{28}$ aprašo visus šešis išteklius, tačiau šio straipsnio temai ypatingai svarbus yra intelektinių gebejjimų traktavimas. Autorius skiria tris gebejjimus: (a) gebejjimą sintetinti - pamatyti problemas naujai ir išeiti už konvencinio mąstymo ribų; (b) gebejjimą analizuoti - atpažinti ir atsirinkti idejjas, kurias verta plètoti toliau; (c) gebèjimą paveikti praktinę-kontekstinę aplinką, t. y. įtikinti kitus, kad idèja yra vertinga. Svarbus visų trijų gebejjimų susiliejimas, kadangi vien gebejjimas analizuoti pasireiškia galingu kritiniu, bet ne kūrybiniu mąstymu, vien gebejimas sintetinti duoda daug naujų idejjų, bet neleidžia kruopščiai atrinkti dèmesio vertųjų, o vien gebejjimas paveikti aplinką gali baigtis tuo, kad idejos priimamos ne dèl jų vertès, o dèl ịvaldyto ittikinejjimo meno.

Todèl ugdymo kontekste, siekiant ugdyti kūrybiškumą, ì pagalbą gali būti pasitelktas probleminis mokymas(is), kuris glaudžiai susijęs su kūrybiškumo ugdymu dèl kelių dalykų: probleminis mokymasis gali vykti ịvairiose mokymo aplinkose, jis susideda iš probleminių situacijų, skatinančių studijuojantijj igyti žinių ir kritiškai ịvertinti pasiekiamą informaciją, jis vysto savimokos gebejimus bei darbo grupèse igūdžius. Probleminiame mokymesi labai svarbi mokymosi ir konteksto sąveika ${ }^{29}$. Su kūrybiškumu ypač susijusios aiškiai neapibrèžtų (angl. ill-defined) problemų sprendimų paieškos: tokios problemos ar užduotys / siekiami tikslai (pvz., parašyti simfoniją, suprojektuoti namą ir pan.) leidžia svarstyti daug galimų sprendimo būdų, o ne imtis tik vieno įmanomo teisingo ar žinomo, nepagalvojant apie alternatyvias išeitis. Žiūrint iš šių prieigų, kūrybiškumas traktuojamas kaip iš esmès racionalus reiškinys ${ }^{30}$. İdomūs tyrimai, atskleidžiantys pažinimo ir žinių svarbą kūrybiškumui: tyrèjai aprašo „dešimties metų taisyklę“, kuri, kaip spejjama, galioja daugelyje sričių. Pavyzdžiui, Hayes 1989 m. klasikiniu vadinamas tyrimas rodo, kad 73 iš 76 didžiųjų kompozitorių prireikè bent 10 studijų metų, kol jie sugebejo suskurti šedevrus, ir pasitaikè tik kelios išimtys, kai pakako 8 ar 9 metų $^{31}$. Nors iprasta problemų sprendimo

27 Sternberg, R. J., supra note 10, p. 20.

28 Ibid., p. 21.

29 Tan, O. S., supra note 14.

30 Kozbelt, A.; Beghetto, R. A.; Runco, M. A., supra note 13, p. 30.

31 Hayes, J. R. Cognitive Processes in Creativity. Glover, J. A.; Roning, R. R.; Reynolds, C. R. (eds.). Handbook of Creativity. New York: Plenum, 1989, p. 202-219, cit. Kozbelt, A.; Beghetto, R. A; Runco, M. A. Theories of Creativity. Kaufman, J. C.; Sternberg, R. J. (eds.). The Cambridge Handbook of Creativity. Cambridge: Cambridge University Press, 2010, p. 20-47. 
ir problemų nustatymo procesus ir juos aiškinančias teorijas atskirti $\mathfrak{i}$ atskiras grupes manant, kad būtent problemų nustatymo perspektyva tiria patị kūrybini procesą ir kūrybišką individą, o problemų sprendimo teorijos koncentruojasi ị pažinimo procesą, Kozbelt, Beghetto ir Runco teigia ${ }^{32}$, kad jokio esminio skirtumo tarp šių dviejų perspektyvų iš tiesų nèra: tiesiog problemų radimo procesas yra subjektyvesnis, nukreiptas ị individą, todèl sunkiau tiriamas. Skiriasi tik akcentai, tikslai ir atskirų tyrejų moksliniai interesai. Siūloma sąvoka - „problemos konstravimas“, apimanti abi matymo perspektyvas: ji leidžia aprèpti visus procesus, kuriais siekiama suprasti, suformuluoti problemas ir jų sprendimo būdus bei ieškoti kūrybiškų neapibrèžtų problemų sprendimų.

Saityno 2.0 eroje naujosios technologijos (ypač jų socialinis pobūdis) leido plačiai naudotis kūrybos priemonèmis, kūrinių publikavimu, vertinimu ir kritikavimu, atsirado naujos kūrybiškumo ugdymo bei skatinimo ir kūrybiškumo produktų viešinimo galimybès. Todèl ir aukštajam mokslui tapo svarbu pasinaudoti būtent socialinių technologijų teikiamomis kūrybiškumo ir daugelio kitų susijusių gebejjimų (skaitmeninio raštingumo, medijų raštingumo, kritinio raštingumo, bendradarbiavimo ir komunikacijos ịgūdžių) ugdymo galimybèmis. Allen, Caple, Coleman ir Nguyen ${ }^{33}$ teigia, kad dèstytojai turi būti kūrybiški, nes jie turi naudotis ir valdyti virtualiąsias mokymo(si) aplinkas, kurti inovatyvias užduotis ir daug eksperimentuoti. Svarbu ir tai, kad kūrybiškumas yra pageidaujama baigiančiųjų universitetus savybė, kurios svarbą pabrèžia darbdaviai - XXI a. žinių ekonomikoje norima išprususių darbuotojų, gebančių rasti naujus, originalius sudètingų problemų sprendimo būdus. Todèl edukologai ir praktikai pabrèžia holistinio ugdymo svarbą ${ }^{34}$, o tyrèjai atkreipia dèmesị ị tokius reiškinius kaip anksčiau minèta „trigubo sraigto sistema“.

Tad turbūt todèl dèl visų prieš tai paminètų dalykų šiandien kūrybiškumas dažnai matomas būtent kaip sisteminis fenomenas, ypač kalbant apie jị platesniame nei vien tik psichologijos kontekste, o kūrybinių užduočių modeliavimas siūlomas kaip efektyvus kūrybiškumo ugdymo būdas ${ }^{35}$. Kūrybiškumas tampa šiuolaikinių žmoniu gyvenimo ipročiu, kurị, kaip ir bet kurị kitą ịprotị, galima skatinti arba slopinti ${ }^{36}$. Aukštojo mokslo institucijos integruoja naująsias technologijas ị studijų procesą, atsižvelgdamos ị šiuolaikinio besimokančiojo poreikius bei pageidaujamus moky-

Kozbelt, A.; Beghetto, R. A.; Runco, M. A., supra note 13, p. 37.

33 Allen, B.; Caple, H.; Coleman, K.; Nguyen, T. Creativity in Practice: Social Media in Higher Education. ASCILITE 2012 Conference Proceedings Future Challenges / Sustainable Futures, 25-28 November 2012, Wellington, New Zealand.

Ibid.

35 Sternberg, R. J. How to Develop Student Creativity. Association for Supervision and Curriculumu Development, Virginia, USA, 1996, cit. Allen, B.; Caple, H.; Coleman, K.; Nguyen, T. Creativity in Practice: Social Media in Higher Education', ASCILITE 2012 Conference Proceedings Future Challenges / Sustainable Futures, 25-28 November 2012, Wellington, New Zealand. 
mosi būdus ir ị tyrimus, rodančius, kad naujosios socialinès technologijos gali būti naudojamos kaip efektyvios kūrybiškumą ugdančios priemonès, kurių pageidauja studentai ir be kurių jau nebeįmanomas šiuolaikinio universiteto ar kitos aukštojo mokslo institucijos supratimas, nors tai ir kelia daug prieštaringų diskusijų dèl greitai besikeičiančių ir nuolat tobulinamų technologijų bei nepakankamai ištirtų problemų, pvz., kaip keičiasi žmogaus, kuris ịtraukiamas ị ịvairiausius tinklus, mąstymas, kaip tai veikia mokymo(si) ir išmokimo, pažinimo procesus, koki poveikị daro vis didejantis vizualumas, linijinio teksto suardymas ir išskaidymas ị hipertekstines nuorodas ir pan. Studentų ir dèstytojų požiūrių tyrimai rodo, kad analitiniai gebejjimai, multimodalinio raštingumo poreikiai, ittinklinto bendravimo bei bendradarbiavimo igūdžių ir kūrybiškumo ugdymas yra ypatingai svarbūs šiuolaikiniame edukaciniame kontekste ${ }^{37}$.

Kai kurie tyrèjai pabrėžia ${ }^{38}$, kad būtina integruoti kūrybiškumo ir reflektavimo igūdžių ugdymą i i ittinklinto mokymo(si) procesą, remdamiesi pragmatinèmis prieigomis (pvz., de Bono lateralinio mąstymo teorija), Sternbergo investavimo teorija, socialiniu-asmenybiniu ir socialiniu-kognityviniu požiūriais, Czikszentmihalyi sistemų teorija. Bet Muirhead atkreipia demesį ${ }^{39}$, kad, kalbant apie dèstymo metodus, vienos specifinès formulès nèra. Dėstytojams svarbu nepamiršti, kad kūrybiškumas gali igyti ịvairiausias apraiškas skirtinguose kultūriniuose kontekstuose, o motyvacijos - ypač vidinès - vaidmuo kūrybiškumo ugdymui gali būti lemiamas. Amabile (1998 cit. Muirhead 2007) siūlo 6 strategijas vidinei motyvacijai sukelti: įveikiamos užduoties modeliavimas, veiklos laisvès suteikimas, reikiamų išteklių (pvz., čia turimi galvoje santykiai grupeje ir santykiai tarp studentų bei dèstytojų) buvimas, tam tikrų grupės bruožų pasireiškimas, dėstytojo skatinimas bei institucinė parama (pvz., inovacinès technologijos $)^{40}$. Richards ir Irastorza teigia ${ }^{41}$, kad kūrybiškumui ugdyti virtualiose mokymo(si) aplinkose reikia ị tai nukreiptos dėstytojų veiklos, jų požiūrio išsakymo, pateikimo studentams tokių užduočių ir veiklų, kurios suteikia veikimo laisvę ir įvairesnes mokymo(si) galimybes. Dėstytojas gali pabrèžti kūrybiškumo svarbą per dèstymo stilių (pvz., dažnai atkreipdamas dèmesị ị kūrybingų asmenybių pavyzdžius, pats reikšdamas naujas mintis ir požiūrius ir pan.). O naujosios technologijos suteikia papildomų galimybių naudotis ịvairiais informacijos pateikimo formatais, grafika, daugiaterpių technologijų priemonėmis: užduotys turi būti įdo-

37 Vaičiūnienè, V.; Mažeikienė, V.; Valūnaite Oleškevičienė, G. Social Media in Adult Education. Vilnius: Mykolo Romerio universitetas, 2013, p. 76.

38 Richards, J.; Schubert-Irastorza, C. Valuing Creativity in Online Teaching. Journal of Research in Innovative Teaching. 2013, 26(1): 68-79.

39 Muirhead, B. Integrating Creativity into Online University Classes. Educational Technology and Society. 2007, 10(1): 3.

40 Amabile, T. How to Kill Creativity. Harvard Business Review. 1998, 176(5): 76-78, cit. Muirhead, B. Integrating Creativity into Online University Classes. Educational Technology and Society. 2007, 10(1): 1-13.

41 Richards, J.; Schubert-Irastorza, C., op. cit., p. 74-75. 
mios šiuolaikiniam besimokančiajam ir susijusios su gyvenimu ${ }^{42}$. Tačiau neretai tyrejjai kalba ir apie kūrybiškumo vertinimo problemą ${ }^{43}$. Kūrybiškumui ịvertinti (ypač virtualaus mokymo(si) ir ịtinklintos veiklos kontekste) reikalingi alternatyvios priemonès. Richards ir Schubert-Irastorza siūlo tokias priemones: „susitarimą dèl mokymosi pasiekimų" (angl. learning contract) - kokių žinių / igūdžių bus igyta, kokie šaltiniai bus panaudoti, pagal kokius kriterijus bus vertinami darbai ir pan.), refleksiju rašymą, studentų tarpusavio pasiekimų vertinimą pagal iš anksto aptartas rubrikas ${ }^{44}$.

\section{Išvados}

Naujosios technologijos, iš esmès pakeitusios šiuolaikinę švietimo sistemą, jų socialinis pobūdis, mokymo(si) įtinklinimas, pasikeitę besimokančiųjų poreikiai ir polinkiai nūdienos ịtinklintoje visuomenèje, didesnès galimybès pačiam besimokančiajam veikti ir kontroliuoti mokymo(si) procesą (pvz., kada mokytis, ką mokytis, kokiais šaltiniais remtis, kur mokytis ir pan.), kintantis žmogaus mąstymas ir kiti susiję reiškiniai turi būti dar nuodugniau tiriami. Kūrybiškumo raišką ypatingai veikia nuolatinès technologinès inovacijos, veikiančios visas gyvenimo sferas. Būtini tyrimai, kaip mokymas(is) vyksta virtualioje aplinkoje ir kaip virtualumas ir tinklinimasis veikia kūrybiškumą ir patị žmogų. Tyrejjai, tiriantys kūrybiškumo ugdymą ittinklintoje mokymo(si) aplinkoje, kelia tokius svarbius klausimus: su kokiais išbandymais susiduria destytojai, siekdami skatinti studentų kūrybiškumą; kokios yra neigiamos įtinklinto mokymo(si) pasekmès kūrybiškumo ugdymui; kokių igūdžiu bei priemonių reikia dėstytojams, siekiantiems ugdyti studentų kūrybiškumą; kuo skiriasi ar kaip susiję kūrybiškas mąstymas ir kritinis mąstymas (Muirhead 2013). Tačiau norint atsakymų ỉ šiuos klausimus, būtini išsamūs ir moksliškai pagrịsti tolesni tyrimai.

\section{Literatūra}

Allen, B.; Caple, H.; Coleman, K.; Nguyen, T. Creativity in Practice: Social Media in Higher Education. ASCILITE 2012 Conference Proceedings Future Challenges / Sustainable Futures, 25-28 November 2012, Wellington, New Zealand.
Amabile, T. How to Kill Creativity.Harvard Business Review. 1998, 76(5), cit. Muirhead, B. Integrating Creativity into Online University Classes. Educational Technology and Society. 2007, 10(1).

Czikszentmihalyi, M. A Systems Perspective on Creativity. Sternberg, R. J. (ed). 
Handbook of Creativity. New York: Cambridge University Press, 1999.

Etzkowitz, H.; Leydesdorff, L. The Dynamics of Innovation: From National Systems and "Mode 2" to a Triple Helix of University-IndustryGovernment Relations. Research Policy. 2000, 29(2): 109-123 cit. Sales, A.; Fournier, M.; Sénéchal, Y. Knowledge, Communication, Reflexive Creativity and Social Change. Sales, A.; Fournier, M. (eds.). Knowledge, Communication and Creativity. London: SAGE Publications Ltd., 2007.

Hayes, J. R. Cognitive Processes in Creativity. Glover, J. A.; Roning, R. R.; Reynolds, C. R. (eds.). Handbook of Creativity. New York: Plenum, 1989, cit. Kozbelt, A.; Beghetto, R. A.; Runco, M. A. Theories of Creativity. Kaufman, J. C., Sternberg, R. J. (eds). The Cambridge Handbook of Creativity. Cambridge: Cambridge University Press, 2010.

Kozbelt, A.; Beghetto, R. A.; Runco, M. A. Theories of Creativity. Kaufman, J. C., Sternberg, R. J. (eds.). The Cambridge Handbook of Creativity. Cambridge: Cambridge University Press, 2010.

Miliūnaitè, R. Skaitymo ir raštingumo darna: kaip jos siekti? Lietuvos edukologijos universiteto organizuotos konferencijos Visa Lietuva skaito vaikams: raštingumo ugdymas skaitant pranešimas [interaktyvus]. Vilnius, $2013 \mathrm{~m}$. gruodžio 6 d. [žiūrèta 2013-12-20]. <http://www. kalbosnamai.lt/images/dokumentai/ skaitymo_ra\%C5\%A1tingumo\%20konferencija\%202013.pdf>.

Muirhead, B. Integrating Creativity into Online University Classes. Educational Technology and Society. 2007, 10(1).
Richards, J.; Schubert-Irastorza, C. Valuing Creativity in Online Teaching.Journal of Research in Innovative Teaching, 2013, 6(1).

Runco, M. A. Problem Finding, Problem Solving, and Creativity. Norwood, NJ: Ablex, 1994.

Sales, A.; Fournier, M.; Sénéchal, Y. Knowledge, Communication, Reflexive Creativity and Social Change. Sales, A.; Fournier, M. (eds.). Knowledge, Communication and Creativity. London: SAGE Publications Ltd., 2007.

Sternberg, R. J. How to Develop Student Creativity.Association for Supervision and Curriculum Development, Virginia, USA, 1996, cit. Allen, B.; Caple, H.; Coleman, K.; Nguyen, T. Creativity in Practice: Social Media in Higher Education. ASCILITE2012 Conference Proceedings Future Challenges / Sustainable Futures, 25-28 November 2012, Wellington, New Zealand.

Sternberg, R. J. Creativity. Sternberg, R. J.; Lubart, T.; I., Kaufman, J. C.; Pretz, J. E. (eds.). The Cambridge Handbook of Thinking and Reasoning. New York: Cambridge University Press, 2005.

Sternberg, R. J. Creativity as a Habit. Tan, A. G. (ed.). Creativity: A Handbook for Teachers. Singapore: World Scientific Publishing Co. Pte. Ltd., 2007.

Tan, O. S. Problem-based Learning and Creativity. Singapore: Cengage Publishing, 2009.

Vaičiūnienè, V.; Mažeikienè, V.; Valūnaitė Oleškevičienè, G. Social Media in Adult Education. Vilnius: Mykolo Romerio universitetas, 2013.

Weisberg, R. W. Creativity: Understanding Innovation in Problem Solving, Science, Invention, and the Arts. Hoboken, NJ: Wiley, 2006. 


\title{
CREATIVITY, NETWORKED LEARNING/TEACHING AND THE DEVELOPMENT OF DEEPER COGNITIVE SKILLS IN UNIVERSITY STUDIES
}

\author{
Viktorija Mažeikiené, Vilhelmina Vaičiūnienè \\ Mykolas Romeris University, Lithuania
}

Summary. Various interest-driven groups and communities emerge due to human creativity, creative efforts of individuals, contemporary information sharing culture and accumulation of knowledge through networking. Meanwhile, constant innovations give impetus to the development of societal life and its multiple dimensions. The greatest change in education brought by the new technologies, which are still becoming more and more social in their nature, is the emergence of the new paradigm, where the two learning and teaching - processes have become one. Creativity cannot be separated from knowledge building in contemporary society. This article focuses on creativity in relation to networked learning/teaching and the development of deeper cognitive skills of students and draws on three viewpoints from contemporary research literature pertaining to the phenomenon of creativity: Czikszentmihalyi's systems theory, the investment theory developed by Sternberg and Lubart and a group of viewpoints focusing on problem solving and finding. In relation to networked learning/teaching and the development of deeper cognitive skills at university level, creativity may be seen as related to critical literacy - critical reading and writing skills, analytical skills, ability to make judgements about texts, ability to create texts (printed, digital, visual, multimodal, etc.) as well as ability to apply the acquired information and skills in everyday life, work and task performance in order to implement changes in one's social environment. In Web 2.0 era, the new social technologies supply multiple tools for creation, publication, assessment and critique. The tools are very important in education. Higher education institutions face the necessity to make use of the opportunities offered by the technologies so that they remain relevant for students, who need a range of skills to be successful in contemporary society: digital literacy, media literacy, critical literacy, collaboration and communication skills, unlearning old skills and re-learning new skills, i.e. what is often referred to as multiple literacies of the 21st century.

Keywords: creativity, networked learning/teaching, cognitive skills, critical literacy, new techonologies.

Viktorija Mažeikienė, Mykolo Romerio universiteto Politikos ir vadybos fakulteto Filosofijos ir humanistikos instituto lektorè; Edukologijos ir socialinio darbo instituto doktorantè. Mokslinių tyrimų kryptys: edukologija, diskurso analizè, pragmatika, sociolingvistika, vertimas. 
Viktorija Mažeikienė, Mykolas Romeris University, Faculty of Politics and Management, Institute of Philosophy and Humanities, lecturer; Institute of Educational Sciences and Social Work, doctoral student. Research interests: educational sciences, discourse analysis, pragmatics, sociolinguistics, translation.

Vilhelmina Vaičiūnienė, Mykolo Romerio universiteto Politikos ir vadybos fakulteto Filosofijos ir humanistikos instituto docentè. Mokslinių tyrimų kryptys: edukologija, lingvistika, IKT, vertimas.

Vilhelmina Vaičiūnienè, Mykolas Romeris University, Faculty of Politics and Management, Institute of Philosophy and Humanities, Associate Professor. Research interests: educational sciences, linguistics, ICT, translation. 